\title{
Nexus among Psychological Capital, Work-life Balance and Job Satisfaction of Employees in Apparel Industry
}

Sri Lanka Journal of Social Sciences and Humanities Volume 2 Issue 1, February 2022: 85-95 ISSN: 2773 692X (Online), 27736911 (Print) Copyright: (C) 2021 The Author(s)

Published by Faculty of Social Sciences and Languages, Sabaragamuwa University of Sri Lanka Website: https://www.sab.ac.lk/sljssh DOI: http://doi.org/10.4038/sljssh.v2i1.59

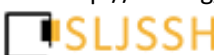

\author{
Anushi, K.S. ${ }^{1}$, Priyanath, H.M.S. ${ }^{1}$ and Tennakoon, W.D.N.S.M. ${ }^{2, *}$ \\ ${ }^{1}$ Department of Economics and Statistics, Sabaragamuwa University of Sri Lanka, Belihuloya, 70140, Sri Lanka. \\ 2 Department of Business Management, Wayamba University of Sri Lanka, Kuliyapitiya, 60200, Sri Lanka.
}

Received: 05 March, 2021, Revised: 16 December, 2021, Accepted: 06 November, 2021.

How to Cite this Article: Anushi, K.S., Priyanath, H.M.S. \& Tennakoon, W.D.N.S.M. (2022). Nexus among psychological capital, worklife balance and job satisfaction of employees in apparel industry. Sri Lanka Journal of Social Sciences and Humanities, 2(1), 85-95.

\begin{abstract}
Work-Life balance and job satisfaction are among the topmost manpower managerial issues in most contemporary workplaces. Fluxes in these variables result in productivity losses and inflated overall cost at the organizational level while at the macro level, they hold back the national economic growth. Scholars argue that psychological capital can positively impact the work-life balance and, subsequently the job satisfaction. Yet, empirical evidence of this nexus is scant, particularly in the context of the Sri Lankan apparel industry. Therefore, this study primarily aimed at exploring the effect of psychological capital on work-life balance and job satisfaction of employees in apparel industries in Sri Lanka. A quantitative inquiry of the research questions was performed. A selfadministrative survey instrument gathered data from a randomly drawn representative sample of 162 employees. Data analysis used descriptive statistics and analytical statistics techniques particularly, Partial Least Square Structural Equation Modeling. Results indicated that all psychological capital antecedents have a significant and positive effect on job satisfaction of apparel employees, among which hope is the strongest influence. Similarly, all psychological capital antecedents except optimism were found to be affecting the work-life balance. Confirmation of the power of psychological capital in manipulating work-life balance and job satisfaction is regarded as the theoretical implication of the study whereas managerial implications highlight the necessity of maintaining the healthy psychological capital state of employees to impact the other desired job-related outcomes.
\end{abstract}

Keywords: Apparel industry, Job satisfaction, Psychological capital, Work-Life balance

\section{INTRODUCTION}

Human capital overrides all the other forms of capital found in organizational setup by its capacity to maximize productivity. It is the only non-substitutable resource that an entity; an organization or a country can be equipped to reach the development targets. Thus, the study and application of positively focused human resources in the organizational setup have been an aged research agenda. Likewise, the psychological capabilities of personnel are identified, measured, developed, and managed effectively for improved performance in the present business world (Margherita, 2021). Because of its positive impact on human resources, Psychological Capital (PsyCap) became very popular in recent years (Tennakoon \& Janadari, 2020). It is theorized that the theories and studies of positive psychology related to the organizational context are acknowledged as PsyCap's tools (Cetin \& Basim, 2012). Successful organizational action that corporate positive psychology into the organizational field is a modern approach that aims at people's growth by highlighting their strengths rather than their weakness (Kotera, Green \& Sheffield, 2021). Studies have shown that PsyCap, with its connection to organizational efficiency, can leverage the organizational performance of all sizes, including the public and private sector institutions (Silveira-Rodrigues, Chambel \& Carvalho, 2021). At the individual level, PsyCap leads to better productivity of employees, performance, Job Satisfaction (JS), lower stress, and reduced turnover (Huffman, Golden, Margherita, 2021).

Work-Life Balance (WLB); an inevitable organizational, managerial and social phenomenon that thrives as women's participation in the labor force increases. The growing number of women in every occupation is found all over the globe. Thereby, WLB has been seen and felt even important today to help families to keep the balance (Tennakoon \& Senarathne, 2020). Job and the family are primary positions in their life for the majority of women and men living in contemporary society (Friedman \& Greenhaus, 2000). Parents need to work increasingly more hours. But time certainly isn't the only problem. Indeed, something that goes a lot deeper than found there is psychological effect and intrusion of work on home and vice versa (Friedman \& Greenhaus, 2000). Research reveals that conflict between work-family and /or family-work erodes job satisfaction (Zhao \& Namasivayam, 2012), hinders work performances (Karatepe, 2013), and amplifies the turnover intention (Karatepe \& Azar, 2013). Yet, favorable WLB leads to greater employee engagement, which in turn result in improved employee productivity and reduced employee turnover. Managers can affect the WLB

\footnotetext{
* Corresponding author: Tel.: +94 71684 3285; Email: tennakoon@wyb.ac.lk

(iD) https://orcid.org/0000-0001-6949-2048
} 
of their employees to a greater extent (Tennakoon \& Senarathne, 2020). The healthier the work-family relationship, the higher will be the employee loyalty towards the organization. Thus, any organization that aims at gaining and sustaining competitive advantage must establish the opportunity to attract, inspire and maintain highly skilled, flexible, and adaptive workers with healthy WLB (Chou \& Robert, 2008). Work-Life imbalances are generally caused by the work demand that may either be below or too low. Some organizations allow employees to take time off for personal matters, while others may take off irregular working hours. The work-family dispute is having greater implications for the individual work outcomes. It impacts career accomplishment and standard of living. Most people face the need to trade off occupation and personal values when looking for ways to balance work and life. Hence, WLB was found critical in affecting the outcomes of both jobs and personal life.

Job Satisfaction (JS) is a complex multidimensional construct that may apply to different people differently. It is a job attitude (Amri, Asbari, Gazali, Novitasari \& Purwanto, 2021). It may be related to any quantitative or qualitative personal sense of achievement. JS is extremely critical for organizational performance and competitiveness due to its particular effect on operation and organizational efficiency. Higher JS can improve the morale and efficiency of workers (Spector, 1997). On contrary, lower JS generates high employee turnover (Amri et al., 2021). Hence, JS can't be overlooked by any organization, as high turnover and absenteeism can adversely impact the organization. Besides the effect on the business, JS plays a significant role in personal well-being too (Talukder \& Galang, 2021). JS is also correlated with the accomplishment of certain goals and the feeling of achievement. Moreover, JS was found to be linked to psychological problems such as anxiety and depression (Talukder \& Galang, 2021). Satisfaction at work is directly connected to happiness and life satisfaction in general (Zelenski et al., 2008). Additionally, it was identified to be positively connected to life satisfaction too (Judge \& Watanabe, 1993). Spector (1997) described JS from a psychological perspective. They stated JS as a process in which employees compare what they want what they received in terms of different aspects of their job (pay, autonomy, workload... etc.). The greater the difference between these two, the lesser will be their happiness at work. However, JS can be raised by several factors, among which PsyCap is reported to be the most intensive inner drive of employees to affect the jobrelated outcomes of employees (Noor, 2011).

Ever since introducing liberalized economic policies in 1977, the private sector plays an important role in the Sri Lankan economy. Among many private-owned industries, the apparel industry is recognized as a principal arm of the private sector due to its contribution to GDP (Gopura \& Indumini, 2021). Job formation, foreign exchange earnings, job opportunities for blue-collar employees, and women's employment opportunities are among the key contributions of the industry. Rural Development Industrialization Program has its goal of reducing the poverty of the rural people through establishing garment factories in various areas to create more employment opportunities (Embuldeniya, 2015). Therefore, the job performance of the employees in the apparel industry is very critical for the Sri Lankan economy. The rapidly shifting global sense raises workplace stress for optimum production and quality enhancement. The apparel industry is too subject to this phenomenon, thus heavily reported for the high levels of labor turnover resulting from job dissatisfaction (Deegahawature \& Rajapaksha, 2020;).
Employers demand their employees to generate optimum outcomes at their job despite the negative job-related attitudes they encounter. WLB, together with JS, determines many other job-related employee outcomes at work. A balanced WLB ensures workers are comfortable at their work. This helps to decrease stress and burnout chances; two rising occupational health issues. It also helps with physical health. The success of an organization depends on its employees. This is where the value of WLB comes into play. If the WLB of an employee is stable, they will be much happier at work, which results in higher productivity. PsyCap is linked to JS as well as life satisfaction. Job dissatisfaction is general for many professions today due to salary level, working environment, workload, overtime, work scheduling... etc. Resultantly, employers witness lower employee efficacy and poor job performance. Inflated labor turnover will be the final result of all these. Besides the importance of these three facets to affect the employee's job-related outcomes, a relatively lesser number of empirical studies are figured in the Asian context. Empirical evidence on PsyCap of employees in the USA and China suggests that there is a positive relationship between PsyCap and job performance. Yet, in the Asian context, particularly in the Sri Lankan context, PsyCap is seldomly addressed. Additionally, no study to the best of the researchers' knowledge in the present context has assessed PsyCap against JS and/or WLB. Essentially, no conceptualization was staged so far in which the mediating effect of WLB is tested. Hence, it is sound to test the nexus between PsyCap, WLB, and JS. Practically, it would be beneficial for managers to deploy the PsyCap in optimizing the WLB and JS of employees at no/ less cost. Thus, the primary motive of this study was to explore the effect of PsyCap on WLB and JS of employees in the Sri Lankan Apparel industry.

\section{THEORETICAL BACKGROUND}

Psychological Capital: The monetary, human, political, technical, physical, intellectual, and social capital no longer permit sustainable competitive advantages. Human capital due to its possession of PsyCap has uplifted the human factors to the forefront (Luthans \& Youssef, 2007). PsyCap has two major distinguishing features. First, it remains in all people, can be measured, developed, and managed for a better outcome. Next, it has a temporal demarcation (approximately 6 months) which is state-like (Luthans \& Youssef, 2007; Luthans et al., 2007). PsyCap can make a constructive impact by generating successful outcomes in human resource growth and work performance (Luthans et al., 2007; Tennakoon, 2017). PsyCap is positive and also a form of intuitional behavior. It is an observable state-like trait that is open to growth and link to positive results of work (Luthans, 2002). PsyCap has four dimensions namely, self-efficacy, hope, optimism, and resilience (Ramalu \& Janadari, 2020).

Self-efficacy refers to one's assessment of its strengths to exert requisite efforts to succeed in hard business (Luthans et al., 2007). It is a core construct derived from Social Cognitive Theory (Bandura, 2008). Stajkovic \& Luthans (1998) put it as a person's faith in his ability to plan for motivation, cognitive recourses, and the way of behaving which is necessary to perform a particular task efficiently. Parker (1998) viewed self-efficacy as the people's ideas about their ability to fulfill specific tasks to the professional marketing. Bandura (2008) described self-efficacy as the decision of people about their capacity to coordinate and execute action necessary to achieve specified kinds of performance. Self-efficacy can be assumed as one of the abilities of an individual (Kim \& Wind- 
sor, 2011). It emphasizes an individual's trust in his/her abilities, but not incompetencies. The employees, before choosing an activity process, assess their skills to accomplish that task.

Optimism is defined as one's style of attribution and exploration (Seligman \& Csikszentmihalyi, 2014). As per the Positive Organizational Behavior (POB) model, optimism considers adverse incidents as outside and out of reach (Seligman \& Csikszentmihalyi, 2014). Some have recognized it as traitlike (Carver et al., 2005) while some have described it as a state-like psychological property (Seligman \& Csikszentmihalyi, 2014). Optimism is independent of hope and confidence (Seligman \& Csikszentmihalyi, 2014). Optimism is an attitude linked to achieving objectives and self-regulation (Peterson, 2000). The optimist is someone who expects positive things to happen, while a pessimist is someone who expects to happen bad things (Carver et al., 2005). Luthans et al. (2007) noted that optimism is correlated with expectations of good thinking events. It is a mindset or behavior combined with an impression of a social or material prospect that the examiner finds to be socially acceptable to his or her benefit or their delight. POB relies on rational optimism that implies improving and reflecting on the positive aspect of our interactions (Schneider, 2001). Optimism is an explanatory approach in that person assigns positive events for inner, stable, worldwide causes and assigns negative events for external, unpredictable, regional causes (Seligman, 2006). In short, optimism refers to life from an emotional and psychological perspective.

Hope stands for people's perseverance in fulfilling organizational objectives (Luthans et al., 2008). It can be measured as being able to reveal important priorities $\&$ goals, as a motivational force, and as a motivational condition like the belief that people should be able to conquer the challenges as they meet to achieve their targets (Cetin \& Basım, 2012). Hope means the conviction that paths to desirable aims can be found and encouraged to use those paths. It comprised 1). Agency (person's strength \& commitment to reach their objectives) and 2). Pathways (intending to fulfill targets and finding alternate paths) (Avey et al., 2009; Snyder, Rand \& Sigmon, 2002; Luthans et al., 2007). Agency, the first element of hope, is explained alternatively as the force of will (Larsen \& Luthans, 2006). Second, the pathways have been viewed as the thoughts people have about their ability to start and keep going on the paths chosen for their goals (Snyder \& Lopez, 2002; Cetin \& Basim, 2012). Combining these components allows people to think and function in such a way that their aims can be accomplished (Rego et al., 2010). The attainment of their organizational objectives is met by the provision of proactivity and creative ways of addressing obstacles.

Resilience is defined as the ability to bounce back from adversity, frustration, and misfortune (Ledesma, 2014). It is considered an essential characteristic of an effective leader (Ledesma, 2014). A direct relationship is reported between the leader's job stress and their ability to maintain resilience in the face of prolonged contact with adversity (Ledesma, 2014). Resilience has stages as survival, recovery, and thriving. Resilience at a given time describes the stage at which a person may be during or after facing adversity. The concept of "thriving" refers to a person's ability to go beyond his or her original level of functioning and to grow and function despite repeated exposure to stressful experiences (Ledesma, 2014). Among the number of variables, those characterize resilience are positive self-esteem, hardiness, strong coping skills, a sense of coherence, self-efficacy, optimism, strong social resources, adaptability, risk-taking, low fear of failure, determination, perseverance, and a high tolerance of uncertainty (Ledesma, 2014). In social sciences, resilience is defined as the ability to recover from negative life experiences and become stronger while overcoming them (Henderson \& Milstein, 2003). Resilience is explained in literature in the context of internal and external factors that contribute to an individual's ability to thrive (Carver et al., 2005). Internal variables in resiliency are defined as self-factors, personality factors, or individual resources. These factors appear to have a significant impact on how a person interprets and deals with the crisis at hand. As such, these factors may include hardiness, coping ability, a sense of coherence, the use of personal resources, cognitive resources, threat appraisal, and self-efficacy. Other internal factors include temperaments such as modes of thought, response, action, positive self-esteem, a sense of being effectual, and being in control of one's surroundings (Beardslee, 1989).

Work-Life Balance: WLB means a relaxed condition of equilibrium between the primary goals of an employee's job status and his/her private lifestyle (Baral \& Bhargava, 2010). WLB activities are essential as it has become a topic of interest to academics as well as business leaders due to the dynamics of the workplace (Baral \& Bhargava, 2010). WLB means the flexible work condition that combines work responsibilities with personal responsibilities. Many employers consider WLB as an important issue at present. Today, every single person must balance conflicting responsibilities and obligations of both jobs and personal life. This is the workplace that has emerged as the issue of WLB. In reality, stressful work-life quest balance is a frequent topic of conversation between both men and women. WLB refers to the capacity of people, regardless of age or gender, to find a rhythm so they can blend their work with their duties in the non-work setup; the desires and expectations. WLB anomalies lead to higher turnover rates, intentions for turnover, and absenteeism (Tennakoon \& Senarathne, 2020). An imbalance typically stems from a lack of sufficient time management support, job duties, personal obligations, and family responsibilities. Competitive work and family pressures are not only tiring, but they can also frustrate, bringing about sickness and absenteeism. It ultimately impinges on efficiency.

Job Satisfaction: Locke (1976) described that JS as a pleasant or optimistic state of mind resulting from an assessment of one's job experience. JS assesses attitude of overall acceptance and enjoys the potential of the employee for the role. JS can be described as a positive impression resulting from work (Robbins et al., 2009). Bushra and Yasir (2014) identified that more about the JS can be derived from their impression of their work. It heavily depends on the match between individual and organization. It may be described as a collection of a person's feelings and beliefs about his work (George \& Jones, 2001). These attitudes can be derived from a satisfaction aspect, or as a complete facet of the job. Simply JS means a feeling of satisfaction in a person's job, that operates as an incentive to work.

According to Lee-Kelley et al. (2007), the performance of workers \& work satisfaction is highly correlated. Additionally, JS was found to affect the employee's turnover intention (Sablynski et al., 2002). Job performance strongly relates to JS (Imran et al., 2014). Emmons (1986) viewed JS as a positive emotion that brings happy life and vice versa. JS is an indication of an employee's emotions (Ogaard et al., 2008). Robbins \& Jude (2003) recognized JS as a subjective valuation of work by an employee. It is also interpreted as a 
positive empathic situation resulting from experience measurement. Employees' positive attitudes are often found causing job performance and satisfaction. Additionally, Goetz et al. (2012) showed JS as an intrinsic factor of human capital. Yet, many extrinsic factors cause job dissatisfaction (Imran et al., 2014). JS is the mindset of individuals towards their employment. JS evaluates how satisfied the respondents are with the job (Jang, Park \& Zippay, 2011). Dimensions of JS often include work itself, wages/incentives for advancement, supervision, co-workers, and relevant work characteristics. Another classification showed five features that constitute overall JS (Hedge \& Borman, 2012). They are working itself, satisfaction with the employer, employee satisfaction, promotion, and compensation. Hirschfeld (2000) interpreted JS as two dimensional; intrinsic and extrinsic satisfaction. The first is the sense of achievement and usage capacity, while the second is employees' emotion about types of work that are related to the job itself, such as work benefit, public relations, and employment policies. Spector (1985) introduced pay, promotion, supervision, benefits, contingent rewards operation procedure, coworkers, nature of work, and communication as the JS dimensions. In contrast, Weiss et al. (1967) have shown ability, utilization, achievement, social status, social service, security, recognition, moral value, independence, creativity, and responsibility as JS dimensions. The present study adopted supervision, communication, professional development, nature of work, and salary as the dimensions of JS (Hedge \& Borman, 2012; Spector, 1985).

\section{DEVELOPMENT OF HYPOTHESES}

The hypothesis is a logically examine relationship between two or more variables described in the types of testable statements. To realize the objective achievement of the study, hypotheses are formed in the light of reviewed literature. Obstacles or difficulties at work serve as challenges and as well the learning opportunities (Luthans \& Youssef, 2007). Those with hopeful feelings, therefore, are more likely to feel better regarding their work and experience greater JS. Leaders with positive hope can drive their subordinates for greater pleasure at work (Luthans, 2002). Duggleby, Cooper, and Penz (2009) have indicated a positive relationship between hope and JS. People of positive hope tend to succeed in goal realization (Luthans, 2002; Snyder, 2000). People strive to reach what they set out to do (Froman, 2010; Hirschfeld, 2000). All this literature evidence supports the hope, as an antecedent of PsyCap, can significantly relate to JS of employees.

$\mathrm{H} 1$ : Hope is positively related to employee job satisfaction. A positive relationship between optimism and JS was found. Luthans \& Youssef (2007) too highlighted the positive effect of PsyCap dimensions (Hope, optimism, and resilience) on JS. The study indicated that the above three dimensions have positively related to JS. The attribution theory posits that optimistic people tend to perform better (Larson \& Luthans, 2006). They assign negative incidents and shortcomings to external triggers, such as individuals or situational factors (Seligman, 2006). They remain positive, even in the face of adverse things that continue to reframe the present positive aspect of such incidents. Building on this literature support, it is assumed that optimism is positively related to employee JS.

H2: Optimism is positively related to employee job satisfaction.
Resilient people appear to be highly self-confident, highly assertive, and tend to have positive results. They are more positive about their jobs and their lives (Mak, Ng \& Wong, 2011). Resilience is positively connected with JS (Larson \& Luthans, 2006). Luthans \& Youssef (2007) identified that greater resiliency results in greater satisfaction at work for various career groups (Matos, Neushotz, Griffin \& Fitzpatrick, 2010). Intervention on collective perceptions of social context will raise work resilience, JS, and job performance (Brown, Wey \& Foland, 2018). Employee stress was significantly yet negatively related to resilience and JS (Chitra \& Karunanidhi, 2013). Furthermore, resilience is positively related to JS and the psychological well-being of a police officer (Zheng et al., 2017). Most referred empirical evidence supports a positive and significant relationship between JS and resilience. Thus, $\mathrm{H} 3$ of the present study assumes that resilience is positively related to employee JS.

H3: Resilience is positively related to employee job satisfaction.

Highly self-efficacious people experience greater flexibility in handling difficulties effectively (Gist \& Mitchel, 1992). As a result, employees can perform well, leading to high JS. A Chinese study concluded a moderating effect of self-efficacy on the relationship between career stressors, strains, and wellbeing (Liu, Schieman \& Jang, 2011). Judge et al. (2001) carried out a meta-analysis to examine the connections between generalized self-efficacy, self-esteem, locus of control, emotional stability, and JS. This study showed a moderately strong relationship of four items with JS. Manozhlovich (2007) indicated that psychological empowerment in the workplace will make employees satisfied, more productive, and effective at their jobs. Law and Guo (2016) revealed that self-efficacy is positively related to JS and organizational commitment. Based on this empirical support, the authors assumed that self-efficacy is positively related to JS.

H4: Self-efficacy is positively related to employee job satisfaction.

PsyCap is positively related to WLB (Sen \& Hooja, 2015). Duggleby, Cooper, \& Penz (2009) revealed that hope is a significant feature of the job of a Continuing Care Assistant. Hope found mediating the relationship between psychological distress and life satisfaction. Hope agency was positively related to instrumental support for action (Roesch et al., 2010). Accordingly, the present study hypothesized that hope is positively related to WLB.

\section{H5: Hope is positively related to WLB}

PsyCap is positively related to WLB (Sen \& Hooja, 2015). Bouzari and Karatepe (2020) identified WLB as boosting the optimism of salespeople. Dyson (2006) revealed a significant relationship between optimism and work-family enrichment \& psychological well-being. He recognized that optimism is positively related to JS, family satisfaction, and life satisfaction. Job demand, optimism, and organizational climate are connected to employee wellbeing and distress in the workplace (Desrumaux, Lapointe, Sima \& Savoie, 2015). A negative effect of stress and lower social support on job optimism is recorded (Taylor, Mclean, Bryce, Abry \& Granger, 2019). A positive relationship was found between gratitude, optimism, and WLB of female teachers in Yogyakarta (Situmorang, Tentama, Mulidin \& Sari, 2019). Hence, the authors suggested a positive association between optimism and WLB.

\section{H6: Optimism is positively related to WLB}

Many researchers have noted a strong association between PsyCap and WLB (Sen \& Hooja, 2015; Kim \& Windsor, 2015). 
Specifically, resilience is good at uplifting the WLB of firstline nurse managers in the Korean nursing workforce. Riley (2012) recognized that resilience, to a greater extent, can control the work-family interferences, resulting in job \& family satisfaction and psychological health. Millear, Liossis, Shochet, Biggs, and Donald (2007) found promoting adult resilience has decreased depression and stress. It aided in raising satisfaction and balancing work and personal lives. Further, Cameron and Browine (2010) emphasized positive attitude and WLB as essential determinants of resilience concerning aged-care nurses. Glass \& Estes in 1997 also identified resilience as a critical measure of personal healing of nurses and midwives. Thus, the present study assumed a positive connection between resiliency and WLB.

\section{H7: Resiliency is positively related to WLB}

Sen and Hooja (2015) have reported greater literature support for a positive relationship between PsyCap and WLB. Chan et al. (2016) found that work to family enrichment and family to work enrichment are positively associated with self-efficacy. They have identified self-efficacy and WLB as positively related. Self-efficacy, JS, and WLB influenced teachers' decision-making (Blackburn, Bunch \& Haynes, 2017). Compared to highly self-efficacious employees, employees with low self-efficacy expect high organizational support (Thakur \& Kumar, 2015). Situmorang and Wijayanthi (2018) revealed that self-efficacy and WLB are related. Yet, gender-based differences were also noted by them. Chan, et al., (2016) examined that self-efficacy and WLB have a significant relationship with JS.

\section{H8: Self-efficacy is positively related to WLB}

Employees are more comfortable with balanced work life and personal life. JS, WLB, and families programs offered by the employers are linked positively. Both work-family and family-work conflicts find negatively related to JS (Bushra \& Yasir, 2014). Burke and Greenglass (1999) identified greater JS and employee commitment where WLB is promoted. Organizational values those support WLB have implications for both men and women. Higher WLB is positively related to JS and negatively related to anxiety (Haar, Russo, Sune \& Malaterre, 2014). Kanwar, Singh, and Kodwani (2009) revealed that WLB is positively associated with the JS of ICT workers. Significant relationships are reported among WLB, JS, and commitment (Azeem \& Akhtar, 2014). Agriculture teachers' JS found related to their WLB (Sorensen \& Mckim, 2014). Moreover, Talukder \& Galang (2021) revealed that WLB and JS are positively associated with organizational commitment while they are negatively associated with work-family conflicts. Thus, the authors, based on the strong empirical foundation, assumed a positive connection between WLB and JS.

\section{H9: WLB is positively related to JS}

PsyCap is found to affect the WLB (Sen \& Hooja, 2015). Moreover, WLB is reported to have both positive and negative effects on JS (Bushra \& Yasir, 2014). Greater JS appeared heightened by JS via employee commitment (Burke \&
Greenglass, 1999). Nevertheless, WLB has hardly been tested specifically for its mediating effect on the PsyCap and JS relationship. Hence, the authors assumed, WLB to mediate the effect of PsyCap on JS.

H10: WLB mediates the relationship between PsyCap and JS

\section{MATERIALS AND METHODS}

The study aimed at gathering empirical support for the casualty among PsyCap, WLB, and JS. The deductive arguments were tested quantitatively based on the data collected through a field survey of employees in the apparel industry of Sri Lanka. The population of the study counted as the employees of the Sri Lankan apparel sector. A simple random sampling technique was equipped to select 162 employees based on two selected garment manufacturing organizations in Baddegama and Galle, Sri Lanka. The researcher constructed a structural questionnaire to gather valuable details and conducted face-to-face interviews.

PsyCap was assessed in terms of four dimensions namely, self-efficacy, optimism, hope, and resiliency (Luthans et al., 2007; Ramalu \& Janadari, 2020) whereas WLB was measured with Work to Personal Life Balance, Personal Life to Work-Life Balance as suggested by Greenhouse \& Beutell (1985). Supervision, communication, professional development, nature of work, and salary were the dimensions of JS (Hedge \& Borman, 2012; Spector, 1985). Standard questionnaires, adopted with slight modifications, measured the key variables particularly, PsyCap - Weiss et al. (1967), and Luthans, Youssef \& Avolio (2007); WLB - Greenhouse and Beutell (1985); JS - Hedge and Borman (2012), and Spector (1985). Both English and Sinhala versions of the questionnaires were used depending on the request by the respondent. The survey instrument consisted of four sections and forty-five (45) items. The first part of the questionnaire carried the questions on demographic factors while the $2^{\text {nd }} 3^{\text {rd }}$ and $4^{\text {th }}$ sections contained the items of PsyCap, JS, and WLB respectively. The data collection process resulted from 162 filled valid responses, which were analyzed using Partial Least Square Structural Equation Modeling (PLS-SEM). The measurement model assessed the reliability and validity tests while the structural model tested the hypotheses. The SmartPLS (Version 2) software facilitated the data analysis.

\section{RESULTS AND DISCUSSIONS}

Relatively identical representation of both gender groups is noted in the sample. Similarly, a fairly equivalent portion of married and unmarried respondents was included in the sample. The majority of respondents are above 30 years old (65.4\%). Most of the employees are Advanced Level qualified (Table 1). Table 1 summarizes the demographic data of the respondents.

Table 1: Demographic Profile of the respondents

\begin{tabular}{lllr}
\hline Variable & & Number & \% \\
\hline \multirow{2}{*}{ Gender } & Female & 95 & 58.60 \\
\cline { 2 - 4 } Age & Male & 67 & 44.14 \\
\hline
\end{tabular}




\begin{tabular}{|c|c|c|c|}
\hline & $21-$ Years 25 & 14 & 08.60 \\
\hline & $25-$ Years 30 & 31 & 19.10 \\
\hline & Years 35- 30 & 53 & 32.70 \\
\hline & Over 35 Years', & 53 & 32.70 \\
\hline & Minimum & 18 Years & \\
\hline & Maximum & 42 Years & \\
\hline \multirow{3}{*}{ Marital Status } & Married & 93 & 57.40 \\
\hline & Unmarried & 69 & 42.60 \\
\hline & Grade 5 to $\mathrm{O} / \mathrm{L}$ & 34 & 21.00 \\
\hline \multirow[t]{2}{*}{ Educational Level } & O/L qualified & 63 & 38.90 \\
\hline & A/L qualified & 65 & 41.10 \\
\hline
\end{tabular}

Source: Survey Data, 2020

The reliability and validity of seven latent variables (Dependent variable - JS, Independent variables - Hope, Resilience, Self-efficacy \& Optimism, and Mediator variable-WLB) were examined based on the PLS-SEM measurement model. Table

$0.7)$ in the first-order reflective measurement model. All the factor loadings were found statistically significant at a 0.05 significance level, hence considered sound indicators of the respective latent constructs.

2 indicates the factor loadings that satisfy the threshold (>

Table 2: Indicator Reliability- First Order Measurement Model

\begin{tabular}{|c|c|c|c|}
\hline Construct & Dimension/ Indicator & Loadings & T Statistics \\
\hline \multirow{15}{*}{$\begin{array}{l}\text { Job Satisfac- } \\
\text { tion }\end{array}$} & Supervision & & \\
\hline & My performance appraisal is conducted on time each year. & 0.904 & 45.99 \\
\hline & My supervisor handles his/her subordinates to the satisfaction of them & 0.847 & 43.09 \\
\hline & Communication & & \\
\hline & $\begin{array}{l}\text { The equipment required for effective communication is widely available } \\
\text { in this organization. }\end{array}$ & 0.920 & 46.81 \\
\hline & Communication between me and other workers is good. & 0.897 & 26.39 \\
\hline & Professional Development & & \\
\hline & The organization provides me with enough work-related training. & 0.943 & 77.44 \\
\hline & $\begin{array}{l}\text { The organization provides me with adequate resources and chances to } \\
\text { develop myself professionally. }\end{array}$ & 0.810 & 10.98 \\
\hline & Nature of Work & & \\
\hline & My job allows me to work independently. & 0.970 & 93.75 \\
\hline & My job goals are clear. & 0.970 & 96.91 \\
\hline & Salary & & \\
\hline & All necessary fringe benefits are provided in my organization. & 0.770 & 17.33 \\
\hline & There are adequate financial rewards for those who work here. & 0.800 & 16.52 \\
\hline \multirow{7}{*}{$\begin{array}{l}\text { Work-Life } \\
\text { Balance }\end{array}$} & Personal Life to Work-Life Balance & & \\
\hline & $\begin{array}{l}\text { I have difficulty getting my work done because I am preoccupied with } \\
\text { personal matters at work. }\end{array}$ & 0.980 & 251.40 \\
\hline & $\begin{array}{l}\text { I am too tired to be effective at work because of things I have going on } \\
\text { in my personal life }\end{array}$ & 0.980 & 218.22 \\
\hline & Work-Life to Personal Life Balance & & \\
\hline & I am happy with the time I spend doing activities not related to work & 0.960 & 118.72 \\
\hline & I can accomplish what I would like in both my personal and work lives & 0.970 & 105.55 \\
\hline & $\begin{array}{l}\text { I often neglect my personal life needs because of the demands of my } \\
\text { work }\end{array}$ & 0.963 & 90.255 \\
\hline
\end{tabular}

Table 3 exhibits that all variables satisfy the internal consistency criterion demonstrated by the Cronbach's Alpha ( $>0.7)$ and the Composite Reliability (>0.7) (Hair, et al., 2012). Furthermore, table 3 indicates the evidence of sound convergent validity AVE (>0.5) (Fornell \& Larcker, 1981). Moreover, the authors noted that the discriminant validity criterion (which is achieved by comparing intercorrelations among the variables with respective square root values of AVE values) is satisfied.

Table 3: Composite Reliability and Convergent Validity

\begin{tabular}{llll}
\hline \multirow{2}{*}{ Variable } & Reliability & Validity \\
\cline { 2 - 3 } & $\begin{array}{l}\text { Composite Reli- } \\
\text { ability }\end{array}$ & Cronbach Alpha & Average Variance Extracted \\
\hline
\end{tabular}




\begin{tabular}{|c|c|c|c|}
\hline Communication & 0.9050 & 0.7907 & 0.8265 \\
\hline Professional development & 0.8763 & 0.7368 & 0.7807 \\
\hline Salary & 0.7681 & 0.3971 & 0.6237 \\
\hline Supervision & 1.0000 & 1.0000 & 1.0000 \\
\hline Nature of work & 0.9717 & 0.9419 & 0.9451 \\
\hline Personal Life to Work-Life Balance & 0.9867 & 0.9732 & 0.9739 \\
\hline Work-Life to Personal Life Balance & 0.9859 & 0.9809 & 0.9461 \\
\hline
\end{tabular}

Having established the essential validity and reliability criteria of the measurement model, the authors tested data for its appropriateness in performing the math model. Their authors adopted multiple regressions in SPSS to obtain VIF and tolerance values as indicators of multicollinearity. VIF values indicated an acceptable level of collinearity, ranging from 1.005 to 3.687 . These values are lower than VIF value 5 , which is an indicator of an insignificant level of multicollinearity among the variables. The tolerance value too showed an acceptable level of multicollinearity as it was ranging from 0.226 to 0.966 (>0.20) (Hair, et al., 2012). This shows that no multicollinearity issues are presented among variables.

Table 4: Path Coefficients and their Significance

\begin{tabular}{|c|c|c|c|c|}
\hline & Beta Value & T Statistics & P-Value & Decision \\
\hline H1: Hope -> JS & 0.348387 & 3.797337 & 0.001 & Supported \\
\hline H2: Optimism -> JS & 0.298034 & 2.187133 & 0.000 & Supported \\
\hline H3: Resilience -> JS & 0.182558 & 2.007820 & 0.022 & Supported \\
\hline H4: Self-efficacy- > JS & 0.190504 & 2.085480 & 0.030 & Supported \\
\hline H5: Hope -> WLB & 0.101911 & 0.576774 & 0.062 & Supported \\
\hline H6: Optimism -> WLB & 0.208627 & 2.057466 & 0.000 & Not Supported \\
\hline H7: Resilience -> WLB & 0.265591 & 1.958585 & 0.041 & Supported \\
\hline H8: Self-efficacy -> WLB & 0.207331 & 1.798320 & 0.025 & Supported \\
\hline H9: WLB -> JS & 0.425149 & 3.954031 & 0.000 & Supported \\
\hline H10: PsyCap -> WLB & 0.303172 & 3.501262 & 0.011 & Supported \\
\hline H11: PsyCap -> JS & 0.254870 & 2.525320 & 0.000 & Supported \\
\hline
\end{tabular}

Table 4 exhibits the path coefficient of variables derived from the assessment of the structural model. There, Beta ( $\beta$ ) values indicate the level of the effect by a certain independent variable over a certain dependent variable while all other possible influencing variables remain constant. The $\mathrm{R}^{2}$ values of the model are 0.3193 and 0.159 for the indirect and direct effects of WLB and PsyCap over JS. It implies a $31.93 \%$ and $15.9 \%$ influence by WLB and PsyCap over JS, respectively. This evidenced a partial mediation of the PsyCap and JS association by the WLB $(31.93>15.9)$. The effect size of these significant paths was found small to medium for PsyCap and JS and PsyCap \& WLB, respectively. Finally, predictive relevance was found, indicating low to medium explanatory power for the variable under the study. 
males are having a unique set of hopes about their personal and career lives based on their age group. For instance, female employees of the 18-25 years age category usually are keeping much hope about their job as the only mean of financing the dowry of their future marriages. Moreover, males of 30- 40 years are highly hopeful about their career growth. Male employees of $40-50$ years of age are in the hope of smooth retirement.

Optimism, the other PsyCap antecedent, is the next best predictor of JS ( $\beta=0.298034,0.000)$. Identical results have been reported by Luthans and Youssef (2007). Optimistic employees enjoy greater JS as they usually see the world in a positive light while pessimistic people don't (Luthans \& Youssef, 2007). Self-efficacious employees too seemed satisfied with their job $(\beta=0.190504,0.030)$. The results of the present study rectify the previous understanding of the same relationship (Law \& Guo, 2016; Judge et al., 2001). People with a strong sense of their ability to perform a certain task often form a positive feeling towards meeting the challenges rather than perceiving them as obstacles. The next arm of the PsyCap, resilience also shows a positive influence on JS ( $\beta=0.182558,0.022)$. Similarly, a positive relationship between resilience and JS has been reported by previous researchers (Larson \& Luthans, 2006; Luthans \& Youssef, 2007; Brown, Wey \& Foland, 2018).

Hypotheses $\mathrm{H} 5-\mathrm{H} 8$ assumed associations between each PsyCap antecedent and WLB. Among them, three of the antecedents, namely optimism, self-efficacy, and resilience, showed a positive and significant relationship with WLB. Among them, resilience is having the strongest relationship with WLB ( $\beta=0.265591,0.0410)$. Resilience has been counted as an individual trait that can affect a range of individual-level behavioral outcomes, so does the WLB too (Millear et al., 2007; Cameron \& Browine, 2010). The property of resilience to be courageous and recover after a setback is often found critical in facing the challenges of work and personal lives. Thus, the connection between these variables can be eye-witnessed in everyone's day-to-day lives.

Next, powerful PsyCap elements that can influence the WLB is the optimism $(\beta=0.208627,0.000)$ and self-efficacy $(\beta=$ $0.207331,0.025)$. Both antecedents were found to have relatively identical impacts over the WLB. These significant associations were further confirmed by the similar findings of the previous studies. Positive imaginations backed by optimism help employees to be happy with the present level of the job and as well as the future accomplishments they expected (Situmorang \& Wijayanti, 2018). Then, this would play a big role in balancing the demands of work and family lives. Further, self-efficacy is also an added value to the WLB. This finding is supported by the recent work by other researchers in the discipline (Chan et al., 2016). Awareness of the own strength to go for certain objectives has a spillover effect on employee motivation. Again, it will generate positive attitudes towards life and performance targets. Hence, the WLB will be greatly affected by the self-efficacy of employees (Duggleby, et al., 2009).

However, the hope, the other PsyCap component found insignificant in affecting the WLB $(\beta=0.101911,0.062)$. Yet, several existing findings support a positive connection between these two variables concerning different contexts (Situmorang \& Wijayanti, 2018; Duggleby, et al., 2009). The inconsistency in the results can be attributable to the routine nature of the join apparel sector and also the limited career paths for further development. Nevertheless, the authors proposed future researches to revisit this association in the light of the different career groups to ratify the results.

Then, the direct and indirect effects of PsyCap on JS were assessed. Both the direct effect; PsyCap over JS $(\beta=$ $0.254870,0.000)$ and the indirect effect; PsyCap and WLB over JS ( $\beta=0.303172,0.011)$ found significant. Introducing the mediator doesn't affect to invade the direct effect, and it is significant even after the introduction of mediator; WLB. However, the effect of the direct path has reduced once the mediator is introduced. That implies the partial mediation of WLB over the relationship between PsyCap and JS (Hair, 2017). Hence, it is concluded that the WLB is partially mediating the relationship between PsyCap and JS. The identical results are noted regarding the association between PsyCap and JS; the direct path (Sorensen \& Mckim, 2014; Talukder, 2019). Yet, the evidence is not presented for the mediating effect of WLB on the relationship between PsyCap. Hence, the researchers claim that the findings of the present study are highly significant as they offer first-hand evidence of a mediating effect of WLB on the relationship between PsyCap and JS. Resultantly; it is expected that the WLB can be used effectively to heighten the impact of PsyCap on JS.

\section{CONCLUSION}

The study aimed at testing the connections among PsyCap, WLB, and JS where PsyCap-was the independent variable, $\mathrm{JS}$, the dependent variable, and the WLB-was the mediating variable. The results indicated that the PsyCap has significant predictive power over the JS. Further, it was revealed that the WLB can mediate this relationship to strengthen the effect of PsyCap over JS. Moreover, all PsyCap antecedents namely, hope, optimism, self-efficacy, and resilience were found to influence the JS significantly. Similarly, three of the antecedents, hope, self-efficacy, and resilience were found to connect to WLB positively, while such evidence was not presented regarding optimism. All the results, except this insignificant relationship, are supported by the prevailing literature. The insignificance of optimism in influencing the JS can be attributed to the contextual differences and also the nature of the job been involved by the respondents. However, the authors invite future researchers in the discipline to revisit the said insignificant relationship.

Apparel industry employees should be competent in managing their work and personal lives, their time, and their money. Overlooked family responsibilities might cause reduced attention to job responsibilities and vice versa. Family-supportive working practices are highly critical for employees to continue their jobs successfully. The flexible management and supervision practices can be also added value. Industry-specific, family-friendly human resource management practices, policies, procedures, and programs can be utilized to improve the employee's satisfaction at work through balanced work and life roles. Administrators should pay attention to implementing policies and procedures minimizing employee work overload, role conflict, and workfamily conflict, enabling apparel workers to have a balanced work and personal life so that the effect of PsyCap on JS can be further strengthened. Adding to that, administrators may improve employees' welfare to lower employee stress. Regular mental health camps can improve employees' psychological health to advance their PsyCap.

The theoretical implications of the study are the confirmation of the PsyCap's ability to impact the JS, including all its antecedents. The study offers empirical evidence on the 
nexus of connections among PsyCap, WLB, and JS in the context of the apparel industry. Authors perceived limited sample size confined to two garment industries and deployment of quantitative research approach only as of the limitations of the study. Hence, future researchers of the discipline are invited to test the same hypotheses in a larger sample, in different industrial contexts, under a mixed research approach. Importantly, the authors believe that a qualitative approach to examine the WLB, a highly subjective core construct, would generate results of different nature.

\section{REFERENCES}

Amri, W. A. A., Asbari, M., Gazali, G., Novitasari, D., \& Purwanto, A (2021). The Effect of religiosity and service quality on job satisfaction: A Case Study of MSME Employees. International Journal of Social and Management Studies, 2 (1), 53-63.

Avey, J., Luthans, F. \& Jensen, S. (2009). Psychological capital: a positive resource for combating employee stress and turnover. Human Resource Management, 48(5), 677-693.

Azeem, S. M., \& Akhtar, N. (2014). The influence of work-life balance and job satisfaction on organizational commitment of healthcare employees. International Journal of Human Resource Studies, 4 (2), 18-26.

Bandura, A. (2008). An agentic perspective on positive psychology. Positive psychology, 1, 167-196

Baral, R., \& Bhargava, S. (2010). Work-family enrichment as a mediator between organizations intervention for work-life balance and job outcomes". Journal of Management Psychology, 274-300.

Beardslee, W. R. (1989). The role of self-understanding in resilient individuals: The development of a perspective. American Journal of Orthopsychiatry, 59(2), 266-278.

Bedeian, A. G., Burke, B. G., \& Moffett, R. G. (1988). Outcomes of workfamily conflict among married male and female professionals. Journa of Management, 14(3), 475-491.

Bouzari, M., \& Karatepe, O. M. (2020). Does optimism mediate the influence of work-life balance on hotel salespeople's life satisfaction and creative performance? Journal of Human Resources in Hospitality \& Tourism, 19 (1), 82-101.

Brown, R., Wey, H., \& Foland, K. (2018). The relationship among change fatigue, resilience, and job satisfaction of hospital staff nurses. Journal of Nursing Scholarship, 50 (3), 306-313.

Burke, R. J., \& Greenglass, E. R. (1999). Work-family congruence and work-family concerns among nursing staff. Canadian Journal of Nursing Leadership, 12 (2), 21-29.

Bushra, A., \& Yasir, A.F. (2014). Impact of work-life balance on job satisfaction and organizational commitment among university teachers: $A$ case study of the University of Gujrat, Pakistan. International Journa of Multidisciplinary Sciences and Engineering, 5(9), 24-29.

Cameron, F., \& Brownie, S. (2010). Enhancing resilience in registered aged care nurses. Australasian journal on aging, 29(2), 66-71.

Carver, C. S., Smith, R. G., Antoni, M. H., Petronis, V. M., Weiss, S., \& Derhagopian, R. P. (2005). Optimistic personality and psychosocia well-being during treatment predict psychosocial well-being among long-term survivors of breast cancer. Health Psychology, 24(5), 508 514.

Çetin, F., \& Basım, H. N. (2012). Örgütsel psikolojik sermaye: Bir ölçek uyarlama çalışması. Amme Idaresi Dergisi, 45(1), 121-137.

Chan, X. W., Kalliath, T., Brough, P., Siu, O. L., O’Driscoll, M. P., \& Timms, C. (2016). Work-family enrichment and satisfaction: The mediating role of self-efficacy and work-life balance. The International Journa of Human Resource Management, 27(15), 1755-1776.

Chitra, T., \& Karunanidhi, S. (2013). Influence of occupational stress, resilience, and job satisfaction on the psychological well-being of policewomen. Indian Journal of Health and Wellbeing, 4 (4), 724.

Chou, R. J. A., \& Robert, S. A. (2008). Workplace support, role overload, and job satisfaction of direct care workers in assisted living. Journal of Health and Social Behavior, 49 (2), 208-222.

Deegahawature, M. M. D. R., \& Rajapaksha, R. A. U. K. (2020). Affect behavior as a determinant of motivation of machine operators in the apparel sector: the moderating effect of employee creativity. Journal of Business, 7 (1), 2020-48.
Desrumaux, P., Lapointe, D., Sima, M. N., Boudrias, J. S., Savoie, A., \& Brunet, L. (2015). The impact of job demands, climate, and optimism on well-being and distress at work: What are the mediating effects of basic psychological need satisfaction? European Review of Applied Psychology, 65 (4), 179-188.

Duggleby, W., Cooper, D., \& Penz, K. (2009). Hope, self-efficacy, spiritual well-being, and job satisfaction. Journal of advanced nursing, 65 (11), 2376-2385.

Dyson-Washington, F. (2006). The relationship between optimism and work-family enrichment and their influence on psychological well-being. Drexel University.

Embuldeniya, A. (2015). Impact of apparel industry on the economy of Sri Lanka. Journal of Social Statistics, 2 (1), 1-14.

Emmons, R. A. (1986). Personal strivings: An approach to personality and subjective well-being. Journal of Personality and Social psychology, 51 (5), 1058.

Friedman, S. D., \& Greenhouse, J. H. (2000). Work and family-allies or enemies? What happens when business professionals confront life choices. Oxford University Press, USA.

Froman, L. (2010). Positive psychology in the workplace. Journal of Adult Development, 17 (2), 59-69.

George, J. M., \& Jones, G. R. (2001). Towards a process model of individual change in organizations. Human Relations, 54 (4), 419-444.

Gist, M., \& Mitchel, T. R. (1992). Self-efficacy: A Theoretical Analysis of Its Determinants and Malleability. Academy Management Review, 183-211.

Glass, J. L., \& Estes, S. B. (1997). The family responsive workplace. Annual review of sociology, 23(1), 289-313.

Goetz, K., Campbell, S. M., Broge, B., Dörfer, C. E., Brodowski, M., \& Szecsenyi, J. (2012). The impact of intrinsic and extrinsic factors on the job satisfaction of dentists. Community dentistry and oral epidemiology, 40 (5), 474-480.

Gopura, S., \& Indumini, N. (2021). The fashion industry in Sri Lanka: The factors affecting the growth. Available at SSRN 3809085.

Greenhouse, J. H., \& Beutell, N. J. (1985). Sources of conflict between work and family roles. Academy of management review, 10(1), 76-88.

Haar, J. M., Russo, M., Suñe, A., \& Ollier-Malaterre, A. (2014). Outcomes of work-life balance on job satisfaction, life satisfaction and mental health: A study across seven cultures. Journal of Vocational Behavior, 85 (3), 361-373.

Hair, J. F., Sarstedt, M., Ringle, C. M., \& Mena, J. A. (2012). An assessment of the use of partial least squares structural equation modeling in marketing research. Journal of the academy of marketing science, 40 (3), 414-433.

Hedge, J. W., \& Borman, W. C. (Eds.). (2012). The Oxford handbook of work and aging. Oxford University Press.

Henderson, N., \& Milstein, M. M. (2003). Resiliency in schools: making it happen for students and educators (Updated ed.). Thousand Oaks, CA: Corwin Press.

Hirschfeld, R. (2000). Does revising the intrinsic and extrinsic subscales of the Minnesota satisfaction questionnaire short form make a difference? Educational Psychology, Mathematical, 60 (2), 255-270.

Huffman, J. C., Golden, J., Massey, C. N., Feig, E. H., Chung, W. J., Millstein, R. A., \& Celano, C. M. (2021). A positive psychology-motivational interviewing program to promote physical activity in type 2 diabetes: The BEHOLD-16 pilot randomized trial. General Hospital Psychiatry, 68, 65-73.

Imran, M. A., Baten, M. A., Nahar, B. S., \& Morshed, N. (2014). Carbon dioxide emission from brickfields around Bangladesh. International Journal of Agricultural Research, Innovation, and Technology, 4 (2), 70-75.

Jang, S. J., Park, R., \& Zippay, A. (2011). The interaction effects of scheduling control and work-life balance programs on job satisfaction and mental health. International Journal of Social Welfare, 20 (2), 135143.

Judge, T. A., \& Watanabe, S. (1993). Another look at the job satisfactionlife satisfaction relationship. Journal of applied psychology, 78 (6), 939-944.

Judge, T. A., Thoresen, C. J., Bono, J. E., \& Patton, G. K. (2001). The job satisfaction-job performance relationship: A qualitative and quantitative review. Psychological Bulletin, 127 (3), 376. 
Kanwar, Y. P.S., Singh, A. K., \& Kodwani, A. D. (2009). Work-life balance and burnout as predictors of job satisfaction in the IT-ITES indus try. Vision, 13 (2), 1-12

Karatepe, O. M. (2013). High-performance work practices and hotel employee performance: The mediation of work engagement. International Journal of Hospitality Management, 32, 132-140.

Karatepe, O. M., \& Azar, A. K. (2013). The effects of work-family conflict and facilitation on turnover intentions: The moderating role of core self-evaluations. International Journal of Hospitality \& Tourism Administration, 14 (3), 255-281.

Kim, M., \& Windsor, C. (2015). Resilience and work-life balance in firstline nurse manager. Asian Nursing Research, 9 (1), 21-27.

Kotera, Y., Green, P., \& Sheffield, D. (2021). Positive Psychology for Mental Wellbeing of UK Therapeutic Students: Relationships with Engagement, Motivation, Resilience, and Self-Compassion. International Journal of Mental Health and Addiction,3 (5), 1-16.

Larson, M., \& Luthans, F. (2006). The potential added value of psychological capital in predicting work attitudes. Journal of leadership \& organizational studies, 13 (1), 45-62.

Law, F. M., \& Guo, G. J. (2016). Correlation of hope and self-efficacy with job satisfaction, job stress, and organizational commitment for cor rectional officers in the Taiwan prison system. International journa of offender therapy and comparative criminology, 60 (11), 1257 1277.

Ledesma, J. (2014). Conceptual Frameworks and Research Models on Resilience in Leadership. SAGE Open. https://doi.org/10.1177/2158244014545464

Liu, E. Y., Schieman, S., \& Jang, S. J. (2011). Religiousness, spirituality, and psychological distress in Taiwan. Review of Religious Research, 53 (2) 137-159.

Locke, E. A. (1976). The nature and causes of job satisfaction. Handbook of industrial and organizational psychology. Chicago: RandMc Narlly, 2 (5), 360-580.

Luthans, F. (2002). Positive organizational behavior: Developing and managing psychological strengths. Academy of Management Perspectives, 16 (1), 57-72.

Luthans, F., \& Youssef, C. M. (2007). Emerging positive organizational behavior. Journal of Management, 33 (3), 321-349.

Luthans, F., Avolio, B. J., Avey, J. B., \& Norman, S. M. (2007). Positive psychological capital: Measurement and relationship with performance and satisfaction. Personnel Psychology, 60 (3), 541-572.

Mak, W. W., Ng, I. S., \& Wong, C. C. (2011). Resilience: enhancing wellbeing through the positive cognitive triad. Journal of counseling psychology, 58 (4), 610.

Manojlovich, M. (2007). Power and empowerment in nursing: Looking backward to inform the future. The Online Journal of Issues in Nurs ing, 12 (1), 2333.

Margherita, A. (2021). Human resources analytics: A systematization of research topics and directions for future research. Human Resource Management Review, https://doi.org/10.1016/j.hrmr.2020.100795.

Matos, P.S., Neushotz, L. A., Griffin, M. T. Q., \& Fitzpatrick, J. J. (2010) An exploratory study of resilience and job satisfaction among psychiatric nurses working in inpatient units. International journal of menta health nursing, 19 (5), 307-312.

Millear, P., Liossis, C., Shochet, I., Biggs, H., \& Donald, M. (2007). Promoting adult resilience in the workplace: Synthesizing mental health and work-life balance approaches. In Psychology Making an Impact: Proceedings of the 42nd Conference of the Australian Psychological Society (pp. 267-271). The Australian Psychological Society Ltd.

Noor, K. M. (2011). Work-life balance and intention to leave among academics in Malaysian public higher education institutions. International journal of business and social science, 2 (11), 67-76.

Øgaard, T., Marnburg, E., \& Larsen, S. (2008). Perceptions of organizational structure in the hospitality industry: Consequences for commitment, job satisfaction, and perceived performance. Tourism Management, 29 (4), 661-671.

Parker, S. K. (1998). Enhancing role breadth self-efficacy: the roles of job enrichment and other organizational interventions. Journal of applied psychology, 83 (6), 835

Peterson, C. (2000). The Fu, American Psychologist, 55 (1), 44-55.
Ramalu, S. S., \& Janadari, N. (2020). Authentic leadership and organizational citizenship behavior: the role of psychological capital. International Journal of Productivity and Performance Management, https://doi.org/10.1108/IJPPM-03-2020-0110.

Rego, A., Marques, C., Leal, S., Sousa, F., \& Pina e Cunha, M. (2010). Psychological capital and performance of Portuguese civil servants: exploring neutralizers in the context of an appraisal system. The International Journal of Human Resource Management, 21(9), 1531-1552.

Riley, D. (2012). Work and family interface: Wellbeing and the role of resilience and work-life balance (Doctoral dissertation), University of Waikato.

Robbins, S. P., \& Judge, T. (2003). Essentials of organizational behavior (Vol. 7). Upper Saddle River, NJ: Prentice-Hall.

Robbins, S., Bergman, R., Stagg, I., \& Coulter, M. (2009). Foundations of Management 3e. Frenchs Forest: NSW: Pearson

Roesch, S. C., Duangado, K. M., Vaughn, A. A., Aldridge, A. A., \& Villodas, F. (2010). Dispositional hope and the propensity to cope: A daily diary assessment of minority adolescents. Cultural Diversity and Ethnic Minority Psychology, 16(2), 191-203.

Sablynski, C. J., \& Lee, T. W. (2002). Turnover: An integration of Lee and Mitchell's unfolding model and job embeddedness construct with Hulin's withdrawal construct. Psychology of Work, 189-203.

Schneider, S. L. (2001). In search of realistic optimism: meaning, knowledge, and warm fuzziness. American Psychologist, 56(3), 250261.

Seligman, M. E. (2002). Positive psychology, positive prevention, and positive therapy. Handbook of positive psychology, 2 (2), 3-12.

Seligman, M. E., \& Csikszentmihalyi, M. (2014). Positive psychology: An introduction. In Flow and the foundations of positive psychology, 5 (12), 279-292

Sen, C., \& Hooja, H. (2015). Psychological Capital \& Work-Life Balance: A study on police officers. International Journal of Management and Social Sciences Research, 4, 7-21.

Silveira-Rodrigues, C., Chambel, M. J., \& Carvalho, V. S. (2021). Positive psychology in the context of peacekeeping militaries: A mediation model of work-family enrichment. International Journal of Environmental Research and Public Health, 18(2), 429.

Situmorang, N. Z., \& Wijayanti, F. (2018). The effect of self-efficacy and gender on the work-family balance of employees in Yogyakarta. In 3rd ASEAN Conference on Psychology, Counselling, and Humanities (ACPCH 2017). Atlantis Press.

Snyder, C. R., \& Lopez, S. J. (2002). The future of positive psychology. Handbook of positive psychology, 751-767.

Sorensen, T. J., \& McKim, A. J. (2014). Perceived work-life balance ability, job satisfaction, and professional commitment among agriculture teachers. Journal of Agricultural Education, 55 (4), 116-132.

Spector, P. E. (1985). Measurement of human service staff satisfaction: Development of the Job Satisfaction Survey. American journal of community psychology, 13 (6), 693-713.

Spector, P. E. (1997). Job satisfaction: Application, assessment, causes, and consequences (Vol. 3). Sage publications.

Stajkovic, A. D., \& Luthans, F. (1998). Self-efficacy and work-related performance: A meta-analysis. Psychological Bulletin, 124, 240-261.

Talukder, A. M. H., \& Galang, M. C. (2021). Supervisor support for employee performance in Australia: Mediating role of work-life balance, job, and life attitude. Journal of Employment Counseling, 58(1), 2-22.

Taylor, M., McLean, L., Bryce, C. I., Abry, T., \& Granger, K. L. (2019). The influence of multiple life stressors during teacher training on burnout and career optimism in the first year of teaching. Teaching and Teacher Education, 86, 102910.

Tennakoon, W.D.N.S.M. (2017). "What makes them different?" The moderating effect of gender towards the association between psychological capital and entrepreneurial orientation. International Journal of Innovative Research and Knowledge, 2(7), 1-18.

Tennakoon, W. D. N. S. M., \& Senarathne, R. B. C. P. (2020). Investigating the determinants of Work-life Balance (WLB): Insights from generation Y Employees in Sri Lanka. South Asian Journal of Social Studies $\begin{array}{llll}\text { and } \quad \text { Economics, } & 8 & \text { (4), } & \text { 142-154. }\end{array}$ https://doi.org/10.9734/sajsse/2020/v8i430226

Tennakoon, W.D.N.S.M., \& Janadari, M.P.N. (2020). The psychological perspective of economic sustainability in the context of Sri Lankan 
SMEs: A Conceptual Paper. Proceedings of the $11^{\text {th }}$ International Conference on Business \& Information; $19^{\text {th }}$ November 2020; University of Kelaniya, Kelaniya. 139-141.

Thakur, A., \& Kumar, N. (2015). The effect of perceived organizational support, role-related aspects and work involvement on work-life balance: Self-efficacy as a moderator. International Journal of Scientific and Research Publication, 5(1), 2250-3153.

Weiss, D. J., Dawis, R. V., England, G. W., \& Lofquist, L. H. (1967). Manual for the Minnesota Satisfaction Questionnaire: Minnesota studies in vocational rehabilitation.

Zelenski, J. M., Murphy, S. A., \& Jenkins, D. A. (2008). The happy, productive worker thesis revisited. Journal of Happiness Studies, 9(4), 521537.

Zhao, X. R., \& Namasivayam, K. (2012). The relationship of chronic regulatory focus to work-family conflict and job satisfaction. International Journal of Hospitality Management, 31(2), 458-467.

Zheng, Z., Gangaram, P., Xie, H., Chua, S., Ong, S. B. C., \& Koh, S. E. (2017) Job satisfaction and resilience in psychiatric nurses: A study at the Institute of Mental Health, Singapore. International Journal of Mental Health Nursing, 26(6), 612-619. 
